\title{
SISTEM PRODUKSI DAN POTENSI PENGEMBANGAN JAGUNG DI KABUPATEN PASAMAN BARAT
}

\section{PRODUCTION SYSTEMS AND POTENTIAL DEVELOPMENT OF CORN IN WEST PASAMAN DISTRICTS}

\author{
Yulmar Jastra \\ Peneliti Bidang Litbang Bappeda Provinsi Sumatera Barat \\ Jl. Khatib Sulaiman No. 1 Padang \\ HP: 085274566068 \\ Email: yulmarjastra@yahoo.com
}

Dikirim: 25 April 2014 Direvisi: 27 Mei 2015 Disetujui: 20 Agustus2015

\begin{abstract}
Abstrak
Jagung (Zea mays L.) merupakan tanaman pangan nasional kedua setelah padi dan perannya semakin meningkat sejalan bertambahnya jumlah penduduk, usaha peternakan, dan berkembangnya industri olahan berbahan baku jagung. Penelitian ini bersifat deskriptif kualitatif dan kuantitatif serta dilakukan secara bertahap yaitu: pra-study dalam rangka pengumpulan informasi tetang kondisi umum dan petani di kabupaten Pasaman Barat, desk study intensif terhadap data luasan dan perkembangan jagung hibrida serta semua informasi yang diperoleh dari kegiatan pra-study; observasi, survey lapangan. Penelitian ini bertujuan : mengidentifikasi system produksi jagung di Pasaman Barat mengidentifikasi potensi pengembangan areal dan analisa usahatani jagung, menyusun Program Aksi Pengembangan jagung di Pasaman Barat. Umur petani jagung di Kabupaten Pasaman Barat antara 40-60 tahun, dengan lama sekolah selama dari 9 tahun dan jumlah anggota keluarga petani 5 orang. Produksi jagung tertinggi di kabupaten Pasaman Barat terjadi pada tahun 2009 sebesar 364.287 ton dengan luas panen 44.793 ha dan produktivitas 6,99 ton/ha, pada tahun 2010 terjadi penurunan produksi menjadi 220.761 ton dengan produktivitas 6,3 ton/ karena terjadinya penurunan luas panen menjadi 33.757 ha. Dan pada tahun 2011 produksi jagung kembali normal dengan produksi 286.078 ton/tahun dengan luas tanam 44.360 ha dan produktivitas 6,50 ton/ha. Potensi lahan yang dapat dimanfaatkan untuk usahatani jagung mencapai 142.850 ha yang didominasi tanah gambut dan mineral masing-masing seluas 7.550 ha dan 16.550 ha. Dari usahatani jagung dapat memberikan keuntungan sebesar Rp 8.860.000,-/ha. Bila masa pertanaman jagung 4 bulan maka pendapatan petani jagung per bulannya sebesar Rp 2.215.000,-

Kata kunci: Jagung, Produksi, Usaha Tani, Pendapatan.
\end{abstract}

\section{Abstract}

Maize (Zea mays L. ) is the second national food crop after rice and its role is increasing in line increase of population, livestock operations, and development of raw material corn processing industry. This research is a descriptive qualitative and quantitative as well as done in stages, namely: pre -study in order neighbor information gathering and general condition of farmers in the districts of West Pasaman, intensive desk study on the extent of data and the development of hybrid corn and all information obtained from pre -study activities; observation, field survey. This study aims to: identify systems of maize production in West Pasaman, identify potential areas of development and analysis of maize farming, Prepare Corn Development Action Programme in West Pasaman. Age maize farmers in West Pasaman between 40-60 years old, with old school for 9 years and the number of family members of farmers 5 . The highest maize production in West Pasaman district occurred in 2009 amounted to 364287 tonnes with 44793 ha of harvested area and productivity of 6.99 tonnes / ha , in 2010, a decline in production to 220761 tonnes with a productivity of 6.3 tons /ha due to a decline in harvested area into 33757 ha. And in 2011 the production of corn production back to normal by 286078 tons / year with 44360 ha of harvested area and productivity of 6.50 tonnes / ha. Potential land that can be used to achieve the 142850 ha of maize farming dominated peat and mineral soil of each area of 7,550 ha and 16,550 ha. Of corn farming can provide a gain of Rp 8,860,000, -/ha. When the period of 4 months of the corn crop corn farmer income per month is Rp 2.215.00,-

Keywords : Maize, Production, Farming, Income. 


\section{PENDAHULUAN}

Sumatera Barat telah mencapai swasembada jagung pada tahun 2006 dimana produksi jagung yang didapat sebesar 202.298 ton dengan kelebihan produksi sebesar 79.122 ton dari kebutuhannya. Peningkatan produksi jagung secara signifikan ini didukung kontribusi Kabupaten Pasaman Barat sebagai sentra utama produksi jagung yang meningkat menjadi 67\% dan didukung Kabupaten Pesisir Selatan, Kabupaten Agam, Kabupaten 50 Kota, dan Kabupaten Tanah Datar sebagai sentra penyangga produksi jagung di Sumatera Barat (Dipertahor, 2009).

Dalam Rencana Strategis Dinas Pertanian Tanaman Pangan dan Hortikultura Sumatera Barat pada tahun 2007 ditargetkan produksi jagung sebesar 183.503 ton pada areal tanam 47.919 ha dengan produktivitas rata-rata 4,04 t/ha. Pada tahun 2010, sasaran produksi jagung ditingkatkan secara signifikan menjadi 217.648 ton dengan menggunakan areal tanam seluas 53.554 ha dan produktivitas rata-rata 4,2 t/ha. Pijakan yang digunakan dalam pengembangan jagung dilakukan melalui optimalisasi pemanfaatan lahan, peningkatan produktivitas, peningkatan pola tanam, peningkatan peran penelitian, pendampingan dan kemitraan, dan program-program khusus yang menciptakan terobosan-terobosan baru (Dipertahor, 2006).

Salah satu program kerja pemerintah Sumatra Barat periode 2010-2015 sebagaimana tersurat dalam Dokumen Rencana Pembangunan Jangka Menengah 2010-2015 adalah peningkatan produksi komoditi strategis Sumatera Barat. Untuk komoditi jagung, ditargetkan produksi Satu Juta ton Jagung dari Sumatera Barat. Kebijakan ini dilatar belakangi oleh masih terjadinya defisit jagung di Sumatera Barat dimana produksinya baru 450 ribu ton, sementara konsumsi jagung mencapai 700 ribu ton. Dengan target produksi 1 juta tersebut diharapkan provinsi ini akan surplus jagung. (Bappeda Sumbar, 2011a).

Gerakan Jagung 1 juta ton ini tak terlepas dari terkait juga dengan adanya usaha peternakan dimana daerah provinsi Sumatera Barat adalah sebagai sumber telur ayam. Pemerintah Provinsi Sumatra Barat mentargetkan menjadi salah satu pusat penghasil telur ayam nasional paling lambat dalam jangka waktu 4 tahun ke depan untuk memasok kebutuhan sejumlah daerah di Sumatra dan Jawa. Peningkatan produksi peternakan telur menjadi salah satu program prioritas dalam RPJM 2010-2015 dimana Pemda mentargetkan produksi telur dari peternakan ayam di Sumatera Barat pada 2015 paling tidak sekitar 76,63 ton (Bappeda Sumbar, 2011b)

Penelitian ini bertujuan: (1) mengidentifikasi system produksi jagung di Pasaman Barat (2) mengidentifikasi potensi pengembangan areal dan analisa usahatani jagung, (3) menyusun Program Aksi Pengembangan Jagung di Pasaman Barat.

\section{METODE}

Penelitian dilaksanakan di Kabupaten Pasaman Barat pada bulan Maret s/d Agustus 2013. Penelitian ini bersifat deskriktif kualitatif dan kuantitatif serta dilakukan secara bertahap yaitu: 1) pra-study dalam rangka pengumpulan informasi tetang kondisi umum kabupaten Pasaman Barat, luas, produksi dan produktifitas jagung, keragaan teknologi petani, serta potensi pengembangan jagung; 2) desk study intensif terhadap data dan semua informasi-informasi yang diperoleh dari kegiatan pra-study; 3) observasi, survey lapangan dalam rangka rekonfirmasi semua data yang telah diperoleh sebelumnya dan mencari data primer sesuai yang dibutuhkan dalam tujuan penelitian ini (Masri S. dan Sofian Effendi. 1982), dan focus group discussion (FGD) dengan melibatkan tim pakar sebagai upaya memperkaya substansi hasil penelitian.

FGD dilakukan untuk mengajak pihak terkait (dinas/indtansi terkait) dan petani menggali masalah dan pengalaman berusaha jagung oleh petani, kondisi kawasan sentra produksi secara holistik dan parameter-parameter penentu perkembangan jagung yang merupakan langkah yang harus dilakukan untuk peningkatan produksi untuk kecukupan jagung sesuai kebutuhan dan stabilitas harga yang pada akhirnya melahirkan program peningkatan produksi dan pendapatan petani jagung dengan pendekatan kawasan sentra dan kawasan potensial (pengembangan baru).

Data yang telah dikumpulkan selanjutnya di analisis secara deskriptif, yaitu dengan menggunakan tabulasi (\% nisbah, rata-rata) dan analisis usahatani jagung (Irawan. B. 2006, dan Soekartawi, et al 1984).

\section{HASIL DAN PEMBAHASAN}

\section{Kondisi Umum Daerah}

Kabupaten Pasaman Barat merupakan wilayah pemekaran yang terbentuk dengan berlakunya Undang-Undang No. 12 tahun 2002. Secara geografis Kabupaten Pasaman Barat merupakan daerah yang dilalui khatulistiwa terletak antara $0^{\circ} 03^{\prime}$ lintang Utara $-0^{\circ} 11^{\prime}$ Lintang Selatan dan antara $99^{\circ} 10-100^{\circ} 04$ Bujur Timur dengan luas wilayah sekitar 3.887,77 $\mathrm{km}^{2}$ atau 9,29\% dari luas wilayah Provinsi Sumatera Barat.

Struktur perekonomian Kabupaten Pasaman Barat sampai tahun 2010 konstribusi yang terbesar masih diberikan oleh sektor pertanian yaitu sebesar 31,69 persen. Dimana sub sektor perkebunan memberikan konstribusi yang terbesar yaitu 19,75 persen, kemudian diikuti oleh sub sektor pertanian tanaman pangan dan hortikultura sebesar 7,58 persen (Bappeda Pasaman Barat, 2011).

Kabupaten Pasaman Barat memiliki potensi tanaman pangan dan palawija yang sangat besar. Ini 
dilihat dari luas tanam tanaman pangan dan Palawija sebesar 19,39 \% dari luas Kabupaten Pasaman Barat. Dari masing-masing jenis tanaman pangan dan palawija, luas tanam yang terbesar dan memiliki potensi yaitu tanaman jagung yaitu dengan luas tanam sebesar 44.492 ha $(59,15 \%)$ dari luas tanaman pangan dan palawija yang ada di Kabupaten Pasaman Barat (Bappeda Pasaman Barat, 2012).

\section{Sistem Produksi Jagung di Kabupaten Pasaman Barat}

\section{a. Profil Petani dan Profil Usahatani}

Berdasarkan hasil wawancara dengan beberapa petani jagung, ternyata bahwa profil petani jagung dengan rata-rata umur petani di Kabupaten Pasaman Barat antara umur 40-60 tahun, sedangkan rata-rata lama sekolah yang dimilki oleh petani jagung adalah berkisar lebih dari 9 tahun (menamatkan pendidikan sampai ke jenjang SLTP), dan dalam hal ini dapat dikatakan bahwa tingkat pendidikan petani jagung masih tergolong relatif rendah.

Ditinjau dari rata-rata jumlah anggota yang terlibat dalam usaha komoditi jagung adalah berasal dari anggota keluarga sendiri. Selanjutnya jika dilihat dari jumlah luas kepemilihan lahan (sawah + kebun) rata-rata adalah sejumlah 1,7 ha, sedangkan jumlah kepemilikan ternak (sapi) adalah lebih 1 (satu) ekor.

Profil usahatani komoditi jagung yang dilaksanakan petani rata-rata sekitar 1,2 ha, dengan produktifitas berkisar antara 6,0 - 6,9 ton/ha, dan potensi pengembangan adalah sekitar $10 \%$ pada lahan gambut dan pada lahan rehabilitasi kebun sawit yang baru ditanam (tanaman sawit sampai umur 2 tahun) dengan teknologi sederhana (Tanpa Olah Tanah).

\section{b. Status teknologi}

Budidaya jagung sebagian besar terkosentrasi pada lahan kering dengan jenis tanah Inceptisols baik tanah gambut maupun mineral dengan tingkat kesuburan tanah sedang sampai tinggi. Sebagai paket teknologi budidaya jagung di Pasaman Barat dapat dilihat pada Tabel 1.

Tabel 1. Teknologi Budidaya Jagung yang Dilaksanakan Petani di Pasaman Barat, Tahun 2012

\begin{tabular}{|c|c|c|}
\hline No & $\begin{array}{l}\text { Komponen } \\
\text { Teknologi }\end{array}$ & Uraian Pelaksanaannya \\
\hline 1 & $\begin{array}{l}\text { Persiapan } \\
\text { Lahan }\end{array}$ & $\begin{array}{l}\text { 1) Persiapan lahan untuk areal pertanaman dilakukan tanpa olah tanah } \\
\text { (TOT) } \\
\text { 2) Semua gulma dan bekas pertanaman sebelumnya disemprot dengan } \\
\text { herbisida } \\
\text { 3) Sisa tanaman sebagai mulsa dipermukaan tanah }\end{array}$ \\
\hline & Penanaman & $\begin{array}{l}\text { 1) Populasi tanaman bervariasi antara } 66.000 \text { sampai } 75.000 \text { tanaman } \\
\text { perhektar } \\
\text { 2) Jarak tanam umunya } 80 \mathrm{~cm} \times 15 \mathrm{~cm} \text { ( } 1 \text { biji per lobang tanam) dengan } \\
\text { membuat lobang tanam }\end{array}$ \\
\hline 3 & Pemupukan & $\begin{array}{l}\text { 1) Paket pemupukan per hektar: Urea : } 200 \text { - } 250 \mathrm{~kg} \text {, TSP/SP-36: } 100 \mathrm{~kg} \text {, } \\
\text { KCl: } 50-75 \mathrm{~kg} \text { atau urea: } 300 \mathrm{~kg}+\text { Ponska } 200 \mathrm{~kg} / \mathrm{ha} \\
\text { 2) Cara pemberian pupuk dilakukan } 2 \text { tahap, yaitu: Pemberian Pupuk } \\
\text { pada umur } 7-10 \text { hari dilakukan petani untuk takaran pupuk } 50 \% \text { urea, } \\
100 \% \text { TSP/SP-36, dan KCl atau } 100 \% \text { Ponska. Pupuk urea tersisa } \\
\text { (50\%) diberikan saat tanaman berumur30-35 hari. Pupuk } \\
\text { organk/kandang } 40 \text { karung }\end{array}$ \\
\hline 4 & $\begin{array}{l}\text { Pemeliharaan } \\
\text { tanaman }\end{array}$ & $\begin{array}{l}\text { 1) Pembumbunan biasanya tidak dilakukan petani Penyiangan gulma } \\
\text { secara herbisida } \\
\text { 2) Pada umumnya petani tidak melakukan pengendalaian hama dan } \\
\text { penyakit tanaman }\end{array}$ \\
\hline 5 & $\begin{array}{l}\text { Panen dan } \\
\text { Pasca Panen }\end{array}$ & $\begin{array}{l}\text { 1) Panen jagung dilakukan petani bila kelobot tongkol telah mengering } \\
\text { berwarna coklat dan biji telah mengeras } \\
\text { 2) Proses pengeringan dilakukan dengan ditebang, dijejerkan kemudian } \\
\text { dibakar } \\
\text { 3) Pemipilan jagung dilakukan oleh pedagang pengumpul (sebagai } \\
\text { pemberi modal kerja) } \\
\text { 4) Pengeringan biji jagung dengan cara dijemur di lantai jemur }\end{array}$ \\
\hline
\end{tabular}

Sumber : Yulmar Jastra (2012)

keluarga petani jagung adalah sejumlah 5 orang, sedangkan mengenai jumlah tenaga kerja keluarga yang terlibat dalam usaha perkebunan jagung adalah antara 2 (dua) sampai 3 (tiga) orang. Dalam hal ini dapat dikatakan hampir sebagaian besar tenaga kerja
Dalam penyiapan lahan, system tanpa olah tanah (TOT) penerapannya lebih efesien dan dapat diaplikasikan dengan baik ditingkat petani Pasaman Barat. Biasanya menggunakan herbisida round up dan gromoxe dengan takaran 2-3 ltr/ha. Petani 
membutuhkan tenaga kerja 4 orang per hektar. Pemupukan dilakukan 2 tahap, yaitu pada umur 7-10 hari dan pada saat tanaman berumur 30-35 hari. Pengendalian hama penyakit jarang dilakukan.Kegiatan panen yang diterapkan petani Kabupaten Pasaman Barat cukup unik dan tidak dilakukan petani di daerah lain. Cara panen jagung dilakukan dengan 3 tahapan, yaitu: (1) mempertahankan tongkol berkolobot sampai kering sekali selama 7-15 hari lebih lama dibandingkan waktu panen normal, (2) batang jagung ditebang dan dijajarkan selama 2 hari, (3) jajaran batang bersama jagung berkelobot dibakar, dan pemetikan buah dilakukan setelah pemadaman api pembakaran . Cara panen ini menghasilkan tongkol yang berwarna hitam dan menurunkan mutu biji jagung. Sistem bakar ini dapat mengakibatkan resiko kebakaran pada lahan gambut dan tanah organik. Panen sistem bakar ini dilakukan petani dengan beberapa pertimbangan sebagai berikut: (1) penekanan biaya panen, (2) penghematan tenaga kerja yang mulai sulit didapatkan di perdesaan, (3) memudahkan pengeringan biji terkait tingginya curah hujan di kawasan ini, dan (4) belum adanya standarisasi mutu hasil untuk menentukan harga. Kerugian sistem bakar cukup signifikan terkait hilangnya sumber pakan ternak sapi yang berasal dari berangkasan tanaman jagung.

\section{c. Luas Panen, Produksi dan Produktivitas Jagung}

Luas panen tanaman jagung di Sumatera Barat pada tahun 2008 seluas 63.219 ha dan pada tahun 2012 seluas 75.657 ha dengan peningkatan rata-rata luas $8,4 \% /$ tahun. Dan produksi jagung pada tahun 2012 sebesar 495.497 ton dengan produsiktivitas sebesar 65,49 kwintal/ha (Tabel 2).
Luas panen, produksi, dan produktivitas jagung di Kabupaten Pasaman Barat tahun 2008 s/d 2012 dapat dilihat pada Tabel 3, 4, dan 5 atau pada Lampiran Gambar 1, 2 dan 3.

Produksi tertinggi jagung tertinggi terdapat pada tahun 2009 sebesar 364.287 ton dengan luas panen 44.793 ha dan produktivitas 6,99 ton/ha. Pada tahun 2010 di Kabupaten Pasaman Barat terjadi penurunan luas panen dan produksi jika dibandingkan dengan tahun 2008 dan 2009, karena terjadinya alih fungsi lahan tanaman pangan ke perkebunan sawit, dan pada tahun 2011 luas panen kembali meningkat menjadi 44.360 ha dengan produksi 286.078 ton

Sebagai daerah sentra jagung di Kabupaten Pasaman Barat adalah kecamatan Kinali, Pasaman, Luhak Nan Duo, Ranah Batahan dan Lembah Melintang. Untuk mengantisipasi alih fungsi lahan tanaman pangan, Pemerintah Kecamatan Kinali yang memiliki luas lahan pangan $\pm 1.683 \mathrm{Ha}$, membuat surat kesepakatan bersama yang berisi tentang kesepakatan dari kelompok tani yang berada di Kecamatan Kinali yaitu:

- Bahwa lahan persawahan di kelompok tani tersebut tidak akan ditanami tanaman lain, selain komoditi tanaman pangan, dan apabila ada yang melanggar kesepakatan ini, akan dilakukan pencabutan tanaman.

- Pengawasan lahan akan dilakukan oleh kelompok

- Keputusan ini tidak boleh diganggu gugat

- Masa berlaku keputusan ini, berlaku mulai ditetapkan surat ini sampai dengan sekurangkurangnya sepuluh tahun kedepan. Surat keputusan tersebut di buat pada Bulan Februari Tahun 2011, dengan ditanda tangani oleh empat orang Kepala Jorong dan diketahui oleh Wali Nagari dan Camat Kinali.

Tabel 2. Perkembangan Tanaman Jagung di Sumatera Barat Tahun 2008-2012

\begin{tabular}{lllllll}
\hline \multirow{2}{*}{ No } & \multirow{2}{*}{ Keterangan } & \multicolumn{5}{c}{ Tahun } \\
\cline { 3 - 6 } & $\mathbf{2 0 0 8}$ & $\mathbf{2 0 0 9}$ & $\mathbf{2 0 1 0}$ & $\mathbf{2 0 1 1}$ & $\mathbf{2 0 1 2}$ \\
\hline \multirow{2}{*}{$\begin{array}{l}\text { Luas Panen (ha) } \\
2\end{array}$} & Produktivitas (Kwt/ha) & 63.219 & 70.882 & 59.801 & 71.116 & 75.657 \\
3 & Produksi (Ton) & 55.65 & 57.11 & 59.24 & 66.35 & 65.49 \\
& & 351.843 & 404.795 & 354.262 & 471.849 & 495.497
\end{tabular}

Sumber: Dinas Pertanian Tanaman Pangan dan Hortikultura Provinsi Sumatera Barat (2013)

Dari tahun 2008 ke 2009 perkembangan tanaman jagung di Sumatera Barat terjadi peningkatan luas panen dari 63.219 ha menjadi 70.882 ha dan tahun 2010 terjadi penurunan luas panen menjadi 59.801 ha karena sebagian kebun jagung sudah beralih fungsi menjadi lahan non jagung, sehingga produksi jagung pada tahun 2010 turun menjadi 354.262 ton. Dan tahun 2011 luas panen kembali meningkat menjadi 71.116 ha dan tahun 2012 luas panen terus meningkat menjadi 75.657 ha.

\section{Potensi Pengembangan Jagung di Pasaman Barat}

Perluasan areal panen dapat diimplementasikan melalui kebijakan pengembangan lahan bukaan baru dan peningkatan indek pertanaman. Kebijakan ini perlu diformulasikan mengingat sentra produksi utama dan penyangga sebagaian besar mengalami alih fungsi lahan budidaya jagung menjadi areal perkebunan kelapa sawit dan tanaman pangan lainnya sebagai sentra produksi utama, kabupten Pasaman Barat menghadapi penyusutan lahan jagung sebesar 49,4\% atau setara dengan 14.331 ha berubah 


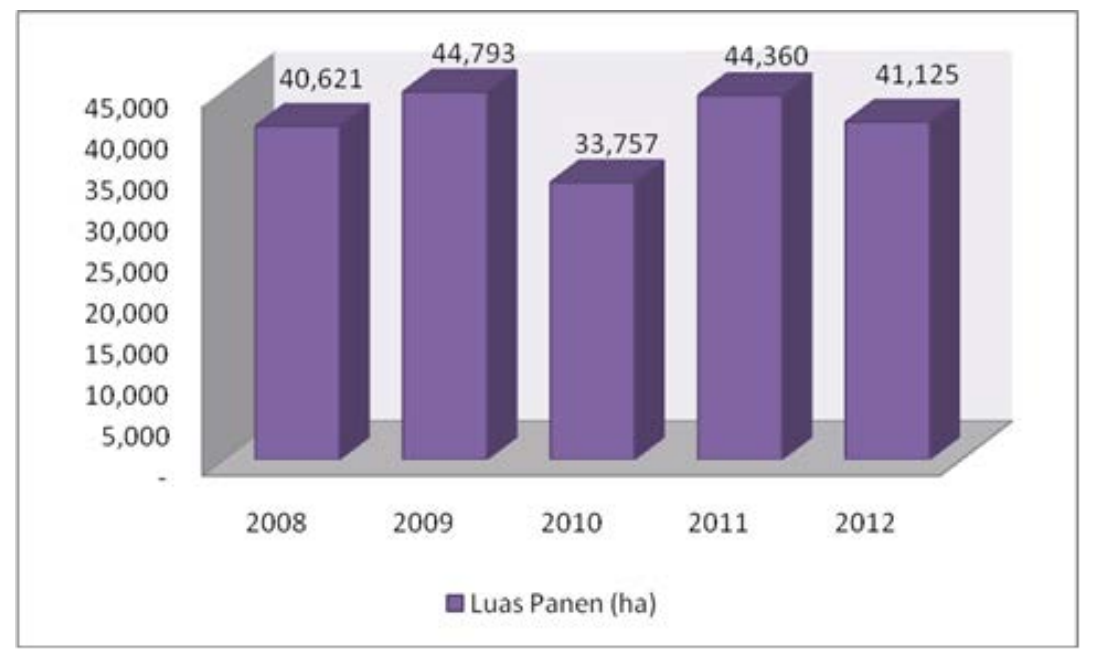

Gambar 1. Luas Panen Jagung di Pasaman Barat

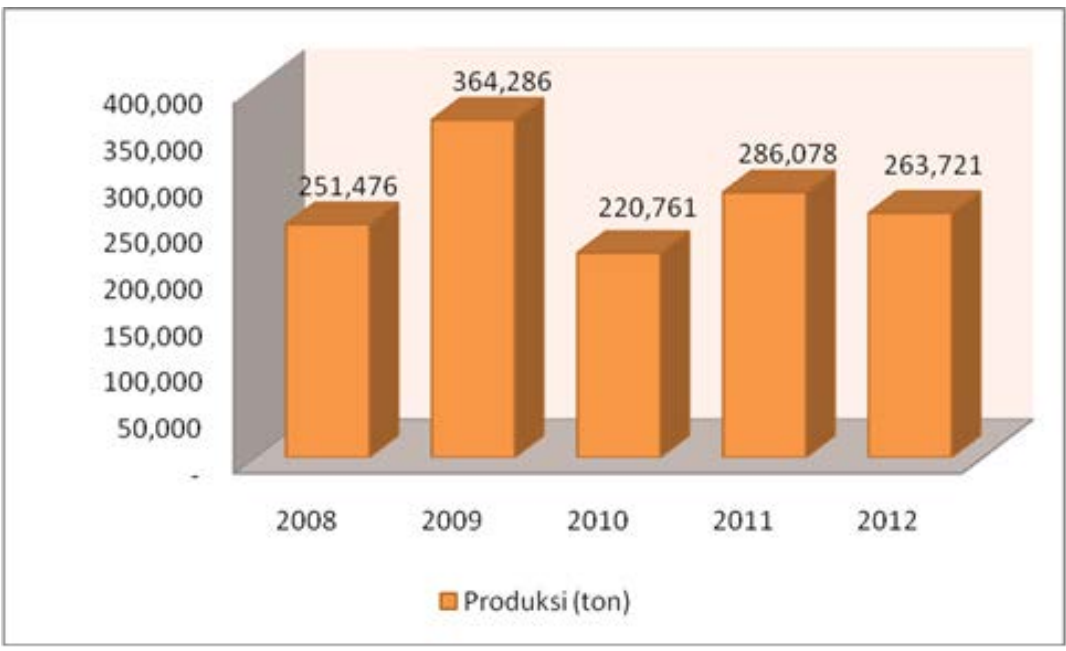

Gambar 2. Produksi Jagung di Pasaman Barat

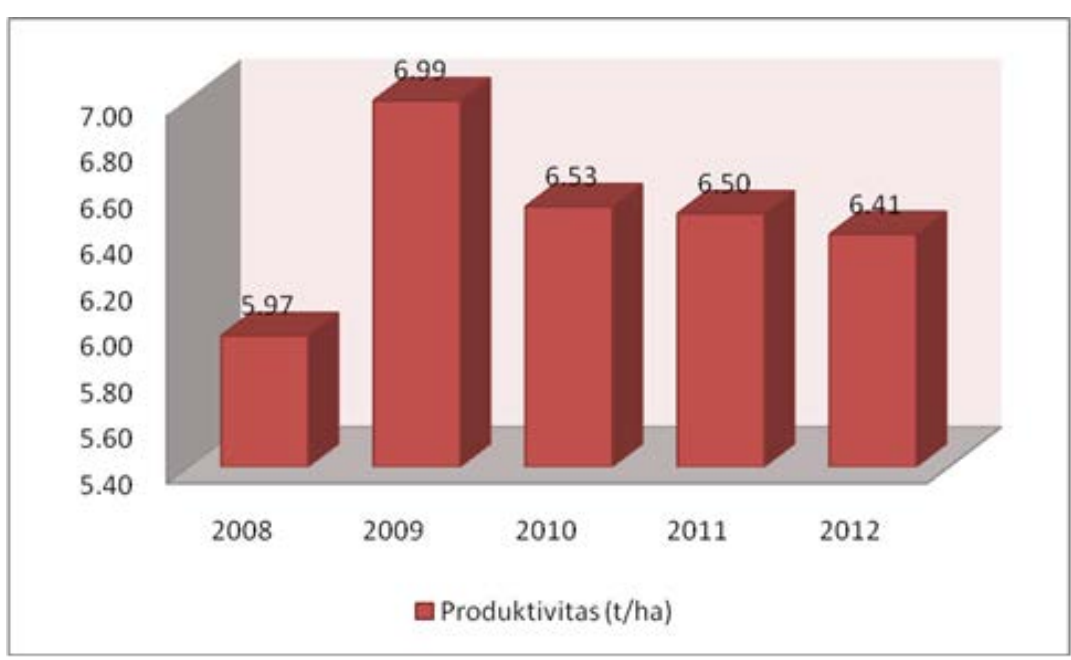

Gambar 3. Produktivitas Jagung di Pasaman Barat 
Tabel 3. Luas Panen Tanaman Jagung di Kabupaten Pasaman Barat tahun 2008-2012

\begin{tabular}{|c|c|c|c|c|c|c|}
\hline \multirow[t]{2}{*}{ No } & \multirow[t]{2}{*}{ Kecamatan } & \multicolumn{5}{|c|}{ Tahun (ha/tahun) } \\
\hline & & 2008 & 2009 & 2010 & 2011 & 2012 \\
\hline 1 & Sungai Beremas & 540 & 552 & 540 & 548 & 866 \\
\hline 2 & Ranah Batahan & 1.603 & 1.890 & 2.911 & 4.033 & 5.406 \\
\hline 3 & Koto Balingka & 1.459 & 1.962 & 2.074 & 853 & 1.620 \\
\hline 4 & Lembah Malintang & 1.807 & 1.601 & 1.481 & 1.577 & 2.724 \\
\hline 5 & Sungai Aur & 948 & 4.315 & 3.134 & 4.604 & 2.529 \\
\hline 6 & G. Tuleh & 1.614 & 1.273 & 832 & 1.110 & 1.052 \\
\hline 7 & Pasaman & 750 & 563 & 544 & 493 & 5.788 \\
\hline 8 & Sasak Ran. Pasisie & 6.032 & 5.374 & 5.736 & 6.368 & 1.166 \\
\hline 9 & Luhak Nan Duo & 4.773 & 4.239 & 3.987 & 3.617 & 3.712 \\
\hline 10 & Kinali & 1.205 & 1.171 & 1.053 & 893 & 15.516 \\
\hline \multirow[t]{2}{*}{11} & Talamau & 19.890 & 21.853 & 11.465 & 20.254 & 746 \\
\hline & JUMLAH & 40.621 & 44.793 & 33.757 & 44.360 & 41.125 \\
\hline
\end{tabular}

Sumber: Dinas Pertanian Pasaman Barat, 2013

Tabel 4. Produksi Jagung di Kabupaten Pasaman Barat tahun 2008-2012

\begin{tabular}{|c|c|c|c|c|c|c|}
\hline \multirow[t]{2}{*}{ No } & \multirow[t]{2}{*}{ Kecamatan } & \multicolumn{5}{|c|}{ Tahun (ton/tahun) } \\
\hline & & 2008 & 2009 & 2010 & 2011 & 2012 \\
\hline 1 & Sungai Beremas & 2.916 & 3.202 & 3.598 & 3.569 & 5.659 \\
\hline 2 & Ranah Batahan & $8.656,2$ & 10.962 & 17.436 & 25.187 & 35.066 \\
\hline 3 & Koto Balingka & $7.878,6$ & 11.380 & 13.731 & 6.036 & 10.928 \\
\hline 4 & Lembah Malintang & $10.119,2$ & 9.766 & 9.536 & 10.274 & 18.239 \\
\hline 5 & Sungai Aur & $5.128,6$ & 33.881 & 22.119 & 31.265 & 15.862 \\
\hline 6 & Gunung. Tuleh & $8.877,0$ & 7.129 & 5.092 & 7.068 & 6.806 \\
\hline 7 & Pasaman & $3.600,0$ & 3.491 & 3.625 & 3.203 & 36.174 \\
\hline 8 & Sasak Ran. Pasisie & 42.827 & 45.211 & 36.076 & 36.502 & 7.511 \\
\hline 9 & Luhak Nan Duo & 37.133 & 39.223 & 326.569 & 25.424 & 24.939 \\
\hline 10 & Kinali & 8.977 & 8.736 & 7.017 & 5.653 & 97.964 \\
\hline \multirow[t]{2}{*}{11} & Talamau & 115.362 & 192.306 & 75.962 & 131.897 & 4.573 \\
\hline & JUMLAH & 251.476 & 364.287 & 220.761 & 286.078 & 263.721 \\
\hline
\end{tabular}

Sumber: Dinas Pertanian Pasaman Barat, 2013

Tabel 5. Produtivitas Tanaman Jagung di Kabupaten Pasaman Barat tahun 2008-2012

\begin{tabular}{|c|c|c|c|c|c|c|}
\hline \multirow[t]{2}{*}{ No } & \multirow[t]{2}{*}{ Kecamatan } & \multicolumn{5}{|c|}{ Tahun (ton/ha) } \\
\hline & & 2008 & 2009 & 2010 & 2011 & 2012 \\
\hline 1 & Sungai Beremas & 5,40 & 5,80 & 6,66 & 6,51 & 6,53 \\
\hline 2 & Ranah Batahan & 5.40 & 5,80 & 5,99 & 6,25 & 6,48 \\
\hline 3 & Koto Balingka & 5,40 & 5,80 & 6,62 & 6,99 & 6,74 \\
\hline 4 & Lembah Malintang & 5,60 & 6,10 & 6,44 & 6,51 & 6,70 \\
\hline 5 & Sungai Aur & 5.41 & 7,85 & 7,06 & 6,79 & 6,27 \\
\hline 6 & G. Tuleh & 5.50 & 5,60 & 6,12 & 6,37 & 6,46 \\
\hline 7 & Pasaman & 4.80 & 6,20 & 6,66 & 6,50 & 6,25 \\
\hline 8 & Sasak Ran. Pasisie & 7,10 & 8,41 & 6,29 & 5,73 & 6,44 \\
\hline 9 & Luhak Nan Duo & 7.78 & 9,02 & 6,66 & 7,03 & 6,72 \\
\hline 10 & Kinali & 7,45 & 7,46 & 6,66 & 6,33 & 6,31 \\
\hline 11 & Talamau & 5,60 & 8,80 & 6,63 & 6,51 & 6,13 \\
\hline & JUMLAH & 5,97 & 6,99 & 6,53 & 6,50 & 6,41 \\
\hline
\end{tabular}

Sumber: Dinas Pertanian Pasaman Barat, 2013

menjadi areal perkebunan kelapa sawit pada tahun 2012. (Informasi Dinas Pertanian)Upaya mempertahankan dan meningkatkan luas lahan baku untuk budidaya jagung di Pasaman Barat dapat dilakukan melalui pemanfaatan potensi lahan peremajaan kelapa sawit berumur lebih dari 17 tahun dengan perincian sebagai berikut:

$>$ Lahan perkebunan kelapa sawit PTPN IV seluas 9.850 ha 
Lahan kelapa sawit rakyat seluas 5.917 ha (15\%x39.450 ha)

> Lahan sawah tadah hujan, irigasi desa, dan irigasi $1 / 2$ teknis seluas 4.789 ha

$>$ Peningkatan IP dengan menanam jagung 10 hari sebelum panen (IP 250 /tahun)

Berdasarkan perhitungan di atas, potensi perluasan lahan usahatani jagung dalam 2-3 tahun pada areal perkebunan kelapa sawit yang di remajakan mencapai 30,556 ha. Bila IP 200 diterapkan maka luas areal panen jagung Pasaman Barat dapat ditingkatkan menjadi 61.112 ha.

Kabupaten Pasaman Barat sebagai sentra utama produksi jagung memiliki potensi lahan sesuai dan yang paling besar ketersediaannya untuk pengembangan jagung. Data hasil pengamatan lapangan menunjukkan bahwa lahan yang dapat dimanfaatkan untuk usahatani jagung mencapai 142.850 ha yang didominasi tanah gambut dan mineral masing-masing seluas 7.550 ha dan 16.550 ha. Sebaran luas lahan Kabupaten Pasaman Barat yang sudah dikembangkan untuk areal pertanaman jagung seluas 90.200 ha (Tabel 6).

Kunci keberhasilan pemanfaatan lahan gambut dan bergambut untuk pertanaman jagung adalah pengaturan tata air makro maupun mikro paket pemupukan dan pengapuran yang tepat, dan penggunaan vareitan unggul yang adaptik. Selanjutnya ' keberhasilan pemanfatan lahan gambut berkaitan erat dengan tingkat ketebalannya. Namun lahan gambut yang luasnya mencapai 39\% dari potensi luas lahan yang sesuai sebagian besar dimanfaatkan untuk pertanaman jagung di Kecamatan Kinali, Luhak Nan Duo, Ranah Pesisir; dan Sungai Aur. Secara umum tanah gambut daerah ini memiliki ketebalan $<1$ meter dengan tingkat kesuburan yang lebih baik dibandingkan tanah gambut yang terdapat di kabupaten pesisir selatan (Mawardi, Jhoniwar, dan Noven. 2009).

\section{Analisa Usahatani Jagung}

Analisis usahatani jagung dilakukan untuk menentukan berapa keuntungan petani yang diperoleh dari usahatani jagung. Dalam analisis usahatani keuntungan dijelaskan dengan hasil produksi dikurangi dengan total biaya produksi dan B/C ratio (Benafit Cost ratio) yaitu keuntungan dibagi dengan total biaya produksi (sarana produksi dan tenaga kerja) (Sukartawi, dkk, 1984). Hasil analisa usahatani jagung di Kabupaten Pasaman Barat dapat dilihat pada tabel 7 :

Nilai B/C ratio diperoleh dengan membandingkan keuntungan dengan total biaya yang di keluarkan yaitu sebesar 1,57 . Nilai B/C sebesar 1,57 ini memberikan arti bahwa setiap biaya (pengeluaran) Rp. 1 maka akan menghasilkan keuntungan sebesar Rp.1,57 atau dengan menggunakan uang sebesar Rp 5.630.000,-/ha dalam usaha tani akan memberikan keuntungan sebesar Rp 8.860.000,-/ha selama 4 bulan (pendapatan petani per-bulannya sebesar Rp. 2.215.000,-. Dari nilai B/C yang diperoleh dengan nilai lebih dari 1 maka dapat dikatakan bahwa usahatani jagung di daerah penelitian menguntungkan untuk diteruskan. Hasil analisa usahatani jagung pada tingkat petani dengan tingkat produktivitas rata-rata 6,9 ton/ha menunjukkan bahwa biaya produksi jagung rata-rata sebesar Rp 816,-/kg.

Jadi usahatani jagung di daerah Pasaman Barat merupakan usahatani yang sangat menguntungkan, hal ini dapat dilihat dari besarnya B/C rasio. Harga jagung di daerah penelitian termasuk tinggi, sehingga keuntungan yang diterima juga lumayan besar. Semakin besar skala usaha, keuntungan yang diterima juga cenderung meningkat. Meskipun demikian, efisiensi teknis belum dapat dicapai dalam usahatani tersebut, hal tersebut dapat dikarenakan masih banyak usahatani yang belum dikelola secara sungguh-sungguh terutama dalam penangan pasca panen. Melihat kondisi usahatani yang belum efisien, cukup besar potensi untuk meningkatkan produksi melalui efisiensi faktor-faktor produksi lainnya.

\section{Kebijakan dan program aksi pengembangan jagung di Pasaman Barat}

Berdasarkan hasil diskusi pada FGD dan tinjauan lapangan pada pertanaman jagung di Kabupaten Pasaman Barat dihimpun permasalahan yang dihadapi petani di lapangan, kemudian di diskusikan lagi dengan penjabat Dinas Pertanian Tanaman Pangan untuk dicarikan jalan keluarnya, maka disusunlah suatu kebijakan dan program aksi Jagung (Tabel 8) yang disarankan untuk dioperasikan oleh Pemda /instansi terkait adalah:

(I) Kebijakan Pengembangan Agribisnis Jagung di Sentra Produksi dengan program utama (1) Program Peningkatan Produksi, Produktivitas, dan Mutu Hasil, untuk menindaklajutinya dilakukan beberapa kegiatan antara lain: a) Pemantapan produktivitas di daerah sentra produksi yang mapan seperti Pasaman Barat (produktifitas $>6,0 \mathrm{t} / \mathrm{ha}$ ) melalui ketersediaan sarana produksi lokalita (benih hibrida, pupuk, pestisida dan peralatan); b) Peningkatan produktifitas melalui penerapan teknologi adaptif dan didukung ketersediaan sarana produksi lokalita (benih hibrida, pupuk, pestisida dan peralatan) pada wilayah produktifitas jagung relative rendah (produktiftas , 6,0 t/ha); c) Perluasan areal tanam jagung dengan memanfaatkan potensi lahan (lahan kering dan sawah tadah hujan) di sentra produksi dan bukan sentra produksi yang potensial.

(II). Kebijakan Pengembangan Infrastruktur Agribisnis Jagung; dengan program utama (1) Program Pengembangan Infrastruktur dan Sarana Pendukung Agribisnis Jagung. Untuk mendukung program ini ada beberapa kegiatan yang akan dianjurkan antara lain: a) Pengembangan infrastruktur seperti jalan usahatani, irigasi teknis untuk sawah dan membangun penangkar benih jagung; b) Membangun kemitraan dengan petanipedagang dan industri pengolahan pakan/peternak 
unggas dengan prinsip saling menguntungkan. Berlaku; c) Fasilitasi ketersediaan sarana dan prasana produksi (benih hibrida, komposit unggul, pupuk dan pestisida dan peralatan) tepat waktu, jumlah dan jenis dengan harga yang layak di setiap sentra produksi

(III) Kebijakan Pemberdayaan Kelembagaan Tani, dan Keuangan, dengan program utama (1) Pemberdayaan Kelembagaan Tani, Penyuluh dan Permodalan, yang didukung dengan kegiatankegiatan antara lain: a) Pemberdayaan Lembaga Keuangan Mikro Agribisnis, Koperasi dan LKM pedesaan serta dukungan skim kredit perbankan untuk pengembangan karet rakyat; b) Pemberdayaan kelembagaan tani (gapoktan/poktan) dan petani; c) Pemberdayaan kelembagaan penyuluhan dan penyuluh melalui pelatihan peningkatan kapasitas Iptek dan manajemen penyuluhan yang efektif.

\section{KESIMPULAN}

Profil Petani komoditi Jagung di Kabupaten Pasaman Barat rata-rata ber-umur 40-60 tahun, sedangkan rata-rata lama sekolah yang dimilki oleh petani jagung adalah berkisar lebih dari 9 tahun (menamatkan pendidikan sampai ke jenjang SLTP). Profil usaha tani komoditi jagung seluas 1,2 ha, produktifitas 6,9 ton/ha, dan potensi pengembangan adalah sekitar $10 \%$ dengan teknologi sederhana (Tanpa Olah Tanah) dan B/C ratio 1,57.

Budidaya tanaman jagung di kabupaten Pasaman Barat dengan sitem tampa olah tanah dengan menggunkanan herbisida, pemakaian pupuk yang berlebihan dan panen dengan system bakar. Produksi jagung tertinggi di kabupaten Pasaman Barat terjadi pada tahun 2009 sebesar 364.287 ton dengan luas panen 44.793 ha dan produktivitas 6,99 ton/ha, pada tahun 2010 terjadi penurunan produksi menjadi 220.761 ton dengan produktivitas 6,3 ton/ karena terjadinya penurunan luas panen menjadi 33.757 ha. Dan pada tahun 2011 produksi jagung kembali normal dengan produksi 286.078 ton dengan luas panen 44.360 ha.

Potensi lahan yang dapat dimanfaatkan untuk usahatani jagung mencapai 142.850 ha yang didominasi tanah gambut dan mineral masingmasing seluas 7.550 ha dan 16.550 ha. Berdasarkan hasil $\mathrm{B} / \mathrm{C}$ ratio diketahui bahwa setiap Rp 1,0 uang yang dikeluarkan petani akan mendapatkan keuntungan sebesar Rp 1,57 atau dengan menggunakan uang sebesar Rp 5.630.000,-/ha dalam usaha tani akan memberikan keuntungan sebesar Rp 8.860.000,-/ha. Bila masa pertanaman jagung 4 bulan maka pendapatan petani jagung per bulannya sebesar Rp 2.215.000,-.

$$
\text { Agar SKPD terkait dapat }
$$
mengimplimentasikan kebijakan program aksi yang telah disusun dalam penelitian ini.

\section{Daftar Pustaka}

Bappeda Sumbar. 2011a. Rencana Pembangunan Jangka Menengah Daerah Provinsi Sumatera Barat tahun 2010-2015. Badan Perencanaan Pembangunan Daerah Propinsi Sumatera Barat.

Bappeda Sumbar. 2011b. Pengembangan Agribisnis Jagung dalam Rencana Tindak/Action Plan 5 Industri Unggulan Sumatera Barat. Bappeda Sumatera Barat.

Bappeda Pasaman Barat, 2012. Profil Daerah Kabupaten Pasaman Barat. Bappeda Kabupaten Pasaman Barat.

Dipertahor Sumbar. 2006. Rencana Strategis Dinas Pertanian Tanaman Pangan dan Hortikultura Propinsi Sumatera Barat Tahun 2006-2010. Dipertahor Sumbar.

Dipertahor Sumbar. 2009. Sasaran produksi bidang pangan Dinas Pertanian Tanaman Pangan Propinsi Sumatera Barat Tahun 2009. Dipertahor Sumbar. Padang Dismpaikan dalam pertemuan peneliti dan penyuluh di BPTP Sumbar pada tanggal 29 September 2009

Irawan. B. 2006. Pelaksanaan PRA dan Rancang Bangun Agibisnis Materi disampaikan pada Workshop Prima Tani di Ciloto tanggal 19-22 September 2006. BBP2TP. Bogor.

Masri S. dan Sofian Effendi. 1982. Metode Penelitian Survai. LP3ES. Jakarta.

Mawardi,E., Jhoniwar, dan Noven. 2009. Kajian Peningkatan Produksi dan Pemasaran Jagung Di Sumatera Barat. Laporan Hasil Penelitian Badan Perencanaan Pembangunan Daerah Sumatera Barat Tahun 2009.

Yulmar Jastra, 2012. Pengembangan jagung hibrida untuk peningkatan pendapatan petani di Pasaman Barat. Jurnal Pembangunan Manusia (Kesehatan, Pendidikan, Ekonomi) Vol. 6 No. 1, April 2012 hal. 64-73. Balitbangnovda Provinsi Sumatera Selatan.

Sukartawi; A. Soeharjo; John L. Dillon dan J. Brian Hardaker. 1984. Ilmu usahatani dan penelitian untuk pengembangan petani kecil. UI. Jakarta. 